\title{
DIAGNOSTIC BIOMARKERS OF EPILEPSY
}

Chiara Sueri $^{1}$, Sara Gasparini ${ }^{1,2}$, Simona Balestrini ${ }^{3}$, Angelo Labate ${ }^{2,4}$, Antonio Gambardella ${ }^{2,4}$, Emilio Russo ${ }^{5}$, Antonio Leo ${ }^{5}$, Silvia Casarotto ${ }^{6}$, Francesca Pittau ${ }^{7}$, Michele Trimboli $^{2}$, Vittoria Cianci $^{1}$, Michele Ascoli ${ }^{2}$, Salvatore M. Cavalli ${ }^{2}$, Giulia Ferrigno ${ }^{2}$, Umberto Aguglia ${ }^{1,2,4}$. Edoardo Ferlazzo $^{1,2,4}$

${ }^{1}$ Regional Epilepsy Centre, Great Metropolitan Hospital, Reggio Calabria, Italy;

${ }^{2}$ Department of Medical and Surgical Sciences, "Magna Græcia” University of Catanzaro, Viale Europa, Germaneto, Catanzaro, Italy;

${ }^{3}$ Department of Clinical and Experimental Epilepsy, UCL Institute of Neurology, London, and Epilepsy Society, Chalfont-St-Peter, Bucks, United Kingdom;

${ }^{4}$ Institute of Molecular Bioimaging and Physiology, National Research Council, Catanzaro, Italy

${ }^{5}$ Science of Health Department, School of Medicine, Magna Græcia University of Catanzaro, Viale Europa, Catanzaro, Italy;

${ }^{6}$ Department of Biomedical and Clinical Sciences "L. Sacco", University of Milan, Milan, Italy;

${ }^{7}$ Institution de Lavigny, Vaud, Suisse.

\section{Corresponding author:}

Umberto Aguglia, MD

Regional Epilepsy Center, BMM Great Metropolitan Hospital,

Via Melacrino, Reggio Calabria, Italy

Tel.: +390965397971; Fax: +390965397973

Email: u.aguglia@unicz.it 


\section{ABSTRACT}

Background: diagnostic biomarkers of epilepsy are objectively measurable variables associated to the development of epilepsy or the propensity to generate seizures. Identification of biomarkers could be helpful for differential diagnosis and for tailored therapeutic approaches.

Objective: this review focuses on diagnostic biomarkers of epilepsy, including genetic, serological, neuroimaging and electrophysiological variables.

Methods: references were mainly identified through PubMed search until December 2017 and backtracking of references in pertinent studies.

Results: several promising diagnostic biomarkers of epilepsy exist, with causative value or predicting liability to develop seizures after acquired brain injuries. Short non-coding RNAs are deregulated in serum and cerebral tissue of epilepsy subjects: these molecules are promising diagnostic biomarkers, being easy to assess and reproducible. Advanced imaging techniques may allow identification of subtle epileptogenic lesions, often with prognostic value. Novel electrophysiological biomarkers of epilepsy include perturbed cortical connectivity and excitability induced by transcranial magnetic stimulation, as well as high-frequency oscillations detected by intracranial and scalp electroencephalographic recordings. Finally, serological biomarkers may support the differential diagnosis between epileptic seizures and non-epileptic events.

Conclusions: ongoing research on diagnostic biomarkers of epilepsy is promising and future preclinical and clinical studies are warranted.

KEYWORDS: genetic, miRNA, HFO, TMS-EEG, prolactin, MRI, seizures. 


\section{INTRODUCTION}

Epilepsy is a highly heterogeneous and multifactorial condition, for which there is a lack of reliable and validated biomarkers. Biomarkers are defined as objectively measurable variables of a biologic process, either physiologic or pathologic, that provide reliable information on the status of that specific process in a specific moment [1]. Since their presence or level correlates with a specific aspect of the process, biomarkers can be artificially divided according to their prevalent diagnostic, prognostic or therapeutic value. Diagnostic biomarkers of epilepsy are aimed to identify the existence and the entity of cerebral tissue propensity to generate seizures or epilepsy and to support differential diagnosis of epileptic seizures [2]. In the current review, we focus on diagnostic biomarkers of epilepsy, including genetic, serological, neuroimaging and electrophysiological variables, and define current unmet needs and future perspectives.

\section{SEARCH STRATEGY}

Publications on diagnostic biomarkers of epilepsy were reviewed. References were identified by PubMed and Scopus search until December 2017, with various combinations of the terms “epilepsy”, “seizures”, “epileptogenesis", “ictogenesis”, “genetics”, “genes”, “miRNA”, “neuroimaging”, “MR”, “hippocampal sclerosis”, “focal cortical dysplasias”, “serological”, “prolactine”, “inflammation”, “EEG”, “TMS”, “electrophysiological”, “HFO”, “biomarker”. Articles were also identified through searches of the authors' own files. Only articles published in English were reviewed. Selection criteria were novelty, importance, originality, quality, and relevance to the scope of this review.

\section{GENETIC BIOMARKERS}

Genetic contribution to epilepsy is increasingly recognized, and consists of a range of different and complex mechanisms [3]. Genotype-phenotype correlation is often not straightforward, with both gain- and loss-of-function variants causing very similar phenotypes but presumably different 
response to treatment $[4,5]$. Each person with epilepsy (PWE) has a complex genetic architecture where genetic variation may contribute to the epileptic phenotype and to develop epileptic seizures (ES) after acquired brain injuries. Some epilepsies have an established genetic etiology, either Mendelian or polygenic. Well-recognized Mendelian inheritance causes numerous focal and generalized syndromes [6]. De novo pathogenic single gene mutations are identified in $30-50 \%$ of patients with different epileptic encephalopathies [7]. Epilepsies with polygenic inheritance imply the involvement of multiple genes. The most common epilepsy syndromes with recognized or suspected polygenic etiology are "idiopathic generalized epilepsies" and "self-limited focal epilepsies" [8]. One of the most intriguing topic of ongoing research is the study of the influence of multiple genes on epilepsy and their interaction with brain lesions (i.e hippocampal sclerosis, HS, focal cortical dysplasia, FCD, etc) or environment (i.e. brain inflammation, trauma, etc). HS is the main cause of mesial temporal lobe epilepsy (TLE) [9]. Genetic susceptibility seems associated with the occurrence of TLE independent of underlying HS. TLE-susceptibility genetic abnormalities include single-nucleotide polymorphisms in the aquaporin-4 gene (Heuser et al, 2010), potassium channel Kir4.1 gene [10], gamma-amino-butyric acid A and B receptor subunit genes [11,12], acid-sensing ion channel 1a gene [13], serotonin-related genes [14-16], calcium homeostasis modulator 1 gene [17], and prodynorphin gene promotor [18]. Genetic variants sometimes appear to influence susceptibility to TLE depending on gender, as for the prion protein gene in males [19], or the neuregulin [20] gene in females. However, none of these findings has been replicated in larger studies [21]. Another field of increasing interest is the involvement of genes influencing inflammation pathways in epileptogenesis. Functional variants in the promoter of the complement C3 gene have been associated with susceptibility to human mesial TLE and febrile seizures [22], and a gene-regulatory network analysis has shown that sestrin 3, a stress responsive protein, acts as positive regulator of a pro-inflammatory transcriptional program in the human epileptic hippocampus [23]. Polymorphisms in pro-inflammatory cytokines genes, such as interleukin (IL) $1 \alpha$ and $1 \beta$, have been associated with TLE, HS, or prolonged febrile convulsions 
[24,25]. A polymorphism of the tissue inhibitor of metalloproteinase 4 gene, encoding for an inflammation-induced apoptosis and matrix turnover factor, has been associated with susceptibility to focal epilepsy in Asian subjects [26]. Also polymorphisms in kelch-like ECH-associated protein 1 and nuclear erythroid 2-related factor 2, implicated in neuroprotection due to induction of antioxidant enzymes, have been linked to susceptibility to TLE and drug-resistant epilepsy [27]. Other genetic variants have been associated to the liability to develop ES or post-traumatic epilepsy. Both ex vivo and in vivo models have shown the role of adenosine and its A1 receptor (A1R) in modulating the severity of status epilepticus [28] and the development of post-traumatic epilepsy [29,30]. Genetic variants in apolipoprotein E [31], glutamic acid decarboxylase 1 [32], neuronal high-affinity excitatory amino acid transporter [33], IL-1 [34], and methylenetetrahydrofolate reductase [35] genes are associated with increased risk of developing post-traumatic ES or epilepsy after traumatic brain injury. Lastly,-functional single-nucleotide polymorphisms in the Cluster of Differentiation 40 [36] and in the mitochondrial aldehyde dehydrogenase 2 genes have been associated with the susceptibility to develop post-stroke epilepsy [37] in single studies. Unfortunately, most of these genetic polymorphisms are not yet of proven value as epilepsy biomarkers since some results have not been replicated and might be specific to certain populations.

\section{SEROLOGICAL BIOMARKERS}

Serological biomarkers of epilepsy include inflammatory proteins, hormones, enzymes and microRNAs (miRNAs). These biomarkers are appealing, since blood, serum, and plasma are easy to obtain.

\subsection{Inflammatory proteins}

Several circulating inflammatory proteins have shown to contribute to ictogenesis in preclinical models of epilepsy $[2,38]$. Although their utility needs to be better clarified, also in consideration of their short half-life and low specificity [2], inflammation molecules have been proposed as serological biomarkers of epilepsy. In particular, IL-6 levels influence neuromodulation and may 
contribute to neuronal network excitability [39]. IL-6 levels are not only a promising biomarker of epilepsy, but may also vary as a function of seizure type and frequency. Indeed, IL-6 blood concentrations are chronically increased in epilepsy patients, especially in TLE subjects, compared with healthy controls [40,41]. Serum levels of IL-6 are significantly increased (compared to baseline) between 3 and $24 \mathrm{~h}$ after a seizure [42]. Post-ictal peak blood concentration of IL-6 is significantly higher after tonic-clonic seizures than after focal seizures, independently from seizure duration $[42,43]$. Among subjects with focal epilepsies, TLE subjects show significantly higher post-ictal peak levels of IL-6. In particular, long seizure duration (i.e., >100s), low seizurefrequency (i.e., < 10 seizures/month), and low baseline (under 5 pg/ml) IL-6 blood levels have been associated to higher IL-6 serum concentration within 24-hours after a seizure, in subjects with TLE [42]. Significantly increased blood levels of IL-6 and other cytokines (i.e., IL-8, IL-1 $\beta$ ) have been shown in subjects with drug-resistant focal epilepsy, independently from the time of their last seizure, compared to healthy controls [44]. Similarly, altered levels of other cytokines (increased IL-8 and epidermal growth factor, lower ratios of IL-1 receptor antagonist (IL-1RA)/IL-1 $\beta$ and IL1RA/IL-8) have been shown in children with febrile status epilepticus compared to children with fever but not ES [45]. A lower ratio of IL-1RA/IL-6 was a strong predictor (OR 21.5, 95\% CI: 1.17-393) of acute hippocampal injury in children with febrile status epilepticus [45]. A 5-fold reduction of blood levels of the anti-inflammatory molecule "telencephalin" in refractory focal epilepsy subjects has also been shown [44].

\subsection{Hormones}

Serum levels of various hormones have been suggested as candidates in the identification of ES. Prolactin (PRL) is the most studied and the most promising hormonal diagnostic biomarker, although its assessment should be performed very soon after a seizure. Its serum levels rise 10-20 minutes after ES and remain high for up to 2 hours, as shown by studies on serial post-ictal PRL measurements in PWE as compared to patients with psychogenic non-epileptic seizures (PNES), 
and healthy controls [46]. Capillary measurement of PRL supports the differential diagnosis between all types of ES and PNES, with an approximate diagnostic sensitivity of 96\% [47] and up to $100 \%$ positive predictive value for ES [48]. It is noteworthy that high PRL values, up to 3-times the baseline level, has also been found within 1 hour after vaso-vagal syncope $[49,50]$ and that its role as diagnostic biomarker of ES has been questioned [51,52].

The role of other hormones (such as cortisol, adrenocorticotropic hormone, growth hormone, and thyrotropin-releasing hormone) has been described in methodologically heterogeneous studies leading to inconsistent results [53-58].

\subsection{Enzymes}

Enzymes have also been suggested as candidate biomarkers of epilepsy. In particular, creatine kinase (CK) blood levels commonly rise after generalized tonic-clonic ES, although elevated CK levels should always be interpreted cautiously, after exclusion of other clinical conditions $[59,60]$. Increased CK levels have $75 \%$ sensitivity, $86 \%$ specificity, $63 \%$ positive predictive value, and $91 \%$ negative predictive value for convulsive ES versus PNES [61-64]. Neuron-specific enolase (NSE) can be elevated after different types of febrile and afebrile seizures [65-68], but not after PNES [61,69]. Noteworthy, increased NSE levels may be found in other conditions (e.g. hemolytic processes) $[70,71]$.

\subsection{Micro-RNAs}

MiRNAs represent an endogenous class of short noncoding RNA molecules, of about 22 nucleotides, which may play a key role in epileptogenesis and ictogenesis by regulating neuronal excitability, morphology, apoptosis and inflammation [72,73]. MiRNAs negatively control gene expression (post-transcriptional gene repression) of target mRNAs [74,75]. They are detected in both biological fluids and brain tissue, bound to proteins or encapsulated into extracellular vesicles. Circulating miRNAs can also be actively secreted from pathological tissues during a disease, and a 
strong relationship between circulating and tissutal miRNAs does exist. Therefore, miRNAs represent non-invasive biomarkers, also in virtue of their stability and simple assessment $[74,76-$ 78]. Up to now, over 100 different miRNAs have been identified in animal models of epilepsy and in PWE [73,77-79]. Table 1 summarises recent studies on miRNAs as diagnostic biomarkers of epilepsy. Most studies are based on a two-phase approach. The first phase consists of the identification of the expression profile of different miRNAs in animal models of epilepsy or in small cohorts of PWE in comparison with a control group. Then, a subsequent validation phase on larger cohorts of PWE is performed. Wang et al. [80] found serum up-regulation of miR-106b-5p, 130a-3p and -146a-5p and down-regulation of miR-15a-5p and -194-5p in 117 TLE patients (regardless epilepsy etiology), compared to 112 healthy controls, with miR-106b-5p showing the highest sensitivity $(80.3 \%)$ and specificity $(81.2 \%)$. Sun et al. [81] found significantly higher expression of miRNA-129-2-3p in plasma samples from refractory TLE subjects, in comparison to healthy controls. Combined serum increased expression of miR-146a and miR-106b has shown a higher sensitivity and specificity in comparison to miR-146a or miR-106b alone [82]. Another study [83] found significant up-regulation of hsa-miR-4521 in serum samples of patients with refractory ES or with FCDs. Despite miRNAs are promising biomarkers of epilepsy, some issues need to be further assessed, such as their specificity for epilepsy and their association (causative vs. consequential) with seizures.

\subsection{Other serological findings}

The role of neuropeptides (i.e., ghrelin and nesfatin-1) is still questioned. One study [84] reported increased serum and salivary nesfatin levels after ES but not after PNES, and lower serum ghrelin levels after ES as compared to PNES. However, the levels of these neuropeptides were not assessed in healthy subjects.

\section{IMAGING BIOMARKERS}


Since 1990s, brain imaging techniques have been routinely applied in the evaluation of PWE [85]. In the last twenty years, a mass of abnormalities has been described in patients with epilepsy, in particular, using routine Magnetic Resonance (MRI) with specific epilepsy protocols as well as morphometric analysis, magnetic resonance relaxometry, diffusion-weighted imaging, MR spectroscopy, volumetry, voxel-based analysis and PET imaging [85-87]. Many of these abnormalities could serve as biomarkers of epilepsy [2]. The use of an optimal worldwide imaging protocol for PWE represents the basis to look for potential and specific biomarkers. MR scanning protocol for PWE must include T1-weighted imaging (for the initial definition of brain anatomy), T2-weighted imaging and fluid-attenuated inversion recovery (FLAIR) imaging for the detection of specific brain pathologies such as hippocampal sclerosis (HS), and 3-D volume acquisition sequences to allow identification of subtle abnormalities, such as malformations of cortical development [85-87]. At present, there are no pathognomonic neuroimaging markers of epileptogenicity. As an example, HS is not only a diagnostic biomarker of mesial TLE, since it may be found in elderly individuals without epilepsy, particularly in those with Alzheimer's disease [88]. The identification of neuroimaging biomarkers might have a high impact on both diagnostic and therapeutic work-up. Engel et al. [1] suggested that a first step to identify potential biomarkers for pharmacoresistance may be to classify several well-defined epilepsy syndromes that are associated with drug resistance but in which there are also patients that are well controlled. In this way, the cohort of patients with mild mesial temporal lobe epilepsy (MTLE), a common and often unrecognized clinical entity with onset in adulthood and good response to the medications [89], symbolizes an ideal epileptic syndrome to be studied with imaging as potential diagnostic/prognostic biomarker. We recently showed that mild MTLE remained drug-responsive in about three-fourths of patients and became refractory in the remaining one-fourth during a mean follow-up > 11 years [90]. In this population, earlier age at onset, history of febrile convulsions and the presence of HS on MRI, represented early prognostic biomarkers of drug-refractoriness [89,91]. Using advanced MRI technique [92-94], we further showed a significant reduction of fractional 
anisotropy along the white matter of the temporal lobes in drug-resistant MTLE, implying that it as a valuable biological marker of refractoriness [95]. Afterwards, we extended these findings and showed diffusion abnormalities and reduced cortical thickness of the corpus callosum only in patients with refractory MTLE, suggesting that differences in the distribution of such alterations might represent a biomarker of refractoriness [96]. Advance of ?Brain imaging has dramatically helped to identify subtle and occult epileptogenic lesions and, thus, to define the etiology of otherwise "cryptogenic" epilepsies. In particular, MRI has contributed significantly to identify cortical malformations and encephaloceles [97-100]. Focal cortical dysplasias (FCDs) are the most common developmental pathologies in children with extratemporal ES and MRI can help to differentiate among FCD subtypes with diagnostic and prognostic implications $[97,99,101]$. Small encephalocele, which may remain occult without careful investigations, is an increasingly recognized cause of epilepsy $[98,102]$. In a case-control study [100], occult temporal encephalocele was found with targeted MRI in 5\% of TLE patients and in none of 151 healthy controls, therefore representing a promising biomarker of epileptogenicity.

\section{ELECTROPHYSIOLOGICAL BIOMARKERS}

The role of electroencephalogram (EEG) in the diagnosis of ES is well-known [103]. The use of transcranial magnetic stimulation (TMS) combined with electromyography as diagnostic biomarker of epilepsy has been already described [104-106]. In the following sections, the role of advanced electrophysiological analysis (i.e., combined TMS-EEG recordings and identification of highfrequency oscillations, HFOs) in the diagnostic workup of PWE will be detailed.

\subsection{TMS/EEG}

EEG is an established tool in PWE that can provide useful information on cortical excitability: its diagnostic application mainly relies on visual inspection and interpretation. TMS is a non-invasive brain stimulation technique that is able to induce local cortical excitation by electromagnetic induction at specified locations properly targeted with an integrated navigation system. TMS has 
initially been applied to the primary motor cortex, thus evoking motor-evoked potentials and, consequently, the appearance of a stereotyped movement. The development of TMS-compatible EEG amplifiers has allowed to record TMS-evoked cortico-cortical potentials, i.e. the electrical brain responses to direct cortical stimulation [107]. Although this approach is technically challenging [108], it allows to investigate the reactivity (i.e. excitability and connectivity) of the whole brain to a focal stimulation delivered over an arbitrary cortical site which can be located outside the primary motor cortex [109-112]. A few studies have performed TMS-EEG in patients with focal [113,114] or generalized [115,116] epilepsies. Valentin et al. [113] have explored the appearance as well as the lateralizing and localizing value of EEG responses to single-pulse TMS applied on different scalp regions in 15 patients with focal epilepsies compared to 15 healthy volunteers. These authors found that late EEG responses, in terms of single epileptiform abnormalities or changes in baseline activity, were evoked in 11/15 PWE and none of the controls and were localizing in most subjects, even in those with normal baseline EEG. TMS-EEG was also applied to the study of patients with periventricular nodular heterotopia. In those patients, late cortical responses were evoked not only in the proximity of lesions, but also in functionally connected regions [114]. These data suggest that late responses to magnetic pulses, typically registered 100-1000 msec after stimulus, may represent a useful biomarker of increased cortical excitability and connectivity in patients with focal epilepsy. TMS-EEG may significantly contribute to epilepsy diagnosis and to the localization of epileptogenic focus also in pre-surgical evaluations. With regard to generalized epilepsies, a study [115] explored the effect of sleep deprivation on EEG activity after TMS in patients with Juvenile Myoclonic Epilepsy and healthy controls. A significant increase in late peak amplitudes (100-190 ms after stimulus) in response to single TMS pulses over motor areas was observed in patients and controls during the sleep-deprived condition, with different topographical distribution (anterior spread) and higher amplitude potentials in patients as compared to controls. In another phase II study [116] a paired-pulse TMS-EEG protocol was applied at rest, during and after hyperventilation and tested for diagnostic accuracy in 25 patients 
with various idiopathic generalized epilepsies (both drug-responsive and drug-resistant) and 11 controls. Features extracted from multi-level analyses of EEG allowed a global diagnostic accuracy of 0.84 for the classification "patients vs. controls" and 0.76 for the classification "resistant vs. nonresistant epilepsy". These studies highlight that TMS-EEG is able to discriminate between healthy controls and PWE, so that the role of this technique as a diagnostic biomarker in epilepsy seems promising. The main limitations of TMS-EEG are the necessity of a dedicated device combining high-density EEG and TMS, technical issues mainly due to handling of artifacts (stimulus artifacts and sensory evoked potentials), long duration of experiments and difficulties in elaboration and interpretation of EEG responses. So far, these limitations have confined TMS-EEG to research laboratories only, preventing its use in clinical practice. Recently, open source software using MATLAB language have been developed and are helpful both in artifact removal and in signal processing and analysis [117]. The reduction in machinery costs and the overcoming of technical issues will hopefully lead to standardization and larger use of this promising technique in the near future.

\subsection{HFOs}

HFOs are defined as EEG events characterized by at least four oscillations, which undoubtedly stand out from the background activity and having frequency ranging between 80 and $500 \mathrm{~Hz}$. HFOs are classified as ripples (from 80 to $250 \mathrm{~Hz}$ ) and fast ripples (> $250 \mathrm{~Hz}$ ), depending on the HFO frequency range. HFO marking is time consuming and nowadays several automatic detection programs are available. To have a complete view on how to record HFOs in epilepsy, refer to Zijlmans et al. [118]. The applications of HFOs detection are expanding over the years, ranging from the identification of seizure onset zone (SOZ) to the assessment of epilepsy severity and monitoring of antiepileptic treatment. According to Jacobs et al. [119], sensitivity in the identification of SOZ (using a pre-set threshold of specificity of 95\%) is 52\% for fast ripples, $37 \%$ for ripples and 33\% for spikes in sleep invasive EEG recordings. Ripples co-occurring with a spike 
may be even more strictly related to the SOZ than ripples without a spike [120,121]. HFOs increase just immediately prior or at the onset of a seizure $[122,123]$. Whereas HFOs are confined to the same epileptogenic area during ictal and interictal periods, spikes are more widespread during seizures than interictally [124]. Resection of cortical areas with pre-surgical high rate of HFO is linked to a better post-surgical outcome than resection of area with low HFO rate [125-129]. HFO rate increases after medication reduction suggesting that it is tightly linked to seizure occurrence [130]. The role of HFOs in differentiating epileptogenic lesions including HS, FCD, nodular heterotopia, polymicrogyria and tuberous sclerosis complex is controversial [131-133]. HFOs can

also be recorded from scalp EEG. HFOs activity on scalp recordings was described at seizures onset in epileptic encephalopathies, such as epileptic spasms in children [134,135] and tonic seizures in Lennox-Gastaut syndrome [136]. HFOs were also recorded in children with electrical status epilepticus during slow wave sleep [136] and in adults with focal epilepsy [137]. Finally, HFOs recorded from scalp EEG may be helpful in the lateralization of the epileptic focus in focal to bilateral convulsive seizures, although they do not differentiate between "primary" and "secondary" bilateral synchrony [138].

\section{CONCLUSIONS}

Numerous studies demonstrate the existence of promising biomarkers in epilepsy. Susceptibility genes are related to polygenic predisposition to epilepsy and represent a new research field in genetics of epilepsy. Promising serological biomarkers of epileptogenicity include inflammation molecules and miRNAs. Hormones, enzymes and neuropeptides serum levels are easy to assess and represent reproducible biomarkers supporting the differential diagnosis between ES and nonepileptic events. Neuroimaging techniques may allow identification of subtle epileptogenic lesions, with diagnostic and prognostic value. Perturbation of cortical connectivity and excitability by TMS and detection of HFOs are promising innovative electrophysiological biomarkers of epileptogenicity. In addition, they are useful to accurately identify SOZ. Future pre-clinical and 
clinical studies are warranted to strengthen the role of these biomarkers in supporting routine clinical practice.

\section{CONFLICT OF INTEREST:}

Dr. Sara Gasparini is currently working with a research grant co-funded by Biogen s.r.l. Dr Simona Balestrini was supported from the Epilepsy Society and The Muir Maxwell Trust. Other authors declare that they have no conflict of interest.

\section{ACKNOWLEDGMENTS}

Chiara Sueri, Sara Gasparini, Umberto Aguglia, Edoardo Ferlazzo: conceived the study, performed the study, collected data, drafted and revised the manuscript.

Simona Balestrini, Angelo Labate, Antonio Gambardella, Emilio Russo, Antonio Leo, Silvia Casarotto, Francesca Pittau, Michele Trimboli, Vittoria Cianci, Michele Ascoli, Salvatore M.

Cavalli and Giulia Ferrigno: performed the study, drafted and revised the manuscript. 


\section{REFERENCES}

[1] Engel, J. Jr; Pitkänen, A.; Loeb, J.A.; Dudek, F.E.; Bertram, E.H. $3^{\text {rd }}$; Cole, A.J.; Moshé, S.L.; Wiebe, S.; Jensen F.E.; Mody, I.; Nehlig, A., Vezzani, A. Epilepsy biomarkers. Epilepsia 2013,54(4),61-69.

[2] Pitkänen, A.; Löscher ,W.; Vezzani, A; Becker, A.J.; Simonato, M.; Lukasiuk, K.; Gröhn, O.; Bankstahl, J.P.; Friedman, A.; Aronica, E.; Gorter, J.A.; Ravizza, T.; Sisodiya, S.M.; Kokaia, M.; Beck, H. Advances in the development of biomarkers for epilepsy. Lancet Neurol 2016,15(8):843-856.

[3] Symonds, J.D.; Zuberi, S.M. Genetics update: monogenetics, polygene disorders and the quest for modifying genes. Neuropharmacology 2017,13. pii: S0028-3908(17)30480-X. doi: 10.1016/j.neuropharm.2017.10.013.

[4] Millichap, J.J.; Miceli, F.; De Maria, M.; Keator, C.; Joshi, N.; Tran, B.; Soldovieri, M.V.; Ambrosino, P.; Shashi, V.; Mikati, M.A.; Cooper, E.C.; Taglialatela, M. Infantile spasms and encephalopathy without preceding neonatal seizures caused by KCNQ2 R198Q, a gain-of-function variant. Epilepsia 2017,58(1),e10-e15.

[5] Wolff, M.; Johannesen, K.M.; Hedrich, U.B.S.; Masnada, S.; Rubboli, G.; Gardella, E.; Lesca, G.; Ville, D.; Milh, M.; Villard, L.; Afenjar, A.; Chantot-Bastaraud, S.; Mignot, C.; Lardennois, C.; Nava, C.; Schwarz, N.; Gérard, M.; Perrin, L.; Doummar, D.; Auvin, S.; Miranda, M.J.; Hempel, M.; Brilstra, E.; Knoers, N.; Verbeek, N.; van Kempen, M.; Braun, K.P.; Mancini, G.; Biskup, S.; Hörtnagel, K.; Döcker, M.; Bast, T.; Loddenkemper, T.; Wong-Kisiel, L.; Baumeister, F.M.; Fazeli, W.; Striano, P.; Dilena, R.; Fontana, E.; Zara, F.; Kurlemann, G.; Klepper, J.; Thoene, J.G.; Arndt, D.H.; Deconinck, N.; Schmitt-Mechelke, T.; Maier, O.; Muhle, H.; Wical, B.; Finetti, C.; Brückner, R.; Pietz, J.; Golla, G.; Jillella, D.; Linnet, K.M.; Charles, P.; Moog, U.; Õiglane-Shlik, E.; Mantovani, J.F.; Park, K.; Deprez, M.; Lederer, D.; Mary, S.; Scalais, 
E.; Selim, L.; Van Coster, R.; Lagae, L.; Nikanorova, M.; Hjalgrim, H.; Korenke, G.C.; Trivisano, M.; Specchio, N.; Ceulemans, B.; Dorn, T.; Helbig, K.L.; Hardies, K.; Stamberger, H.; de Jonghe, P.; Weckhuysen, S.; Lemke, J.R.; Krägeloh-Mann, I.; Helbig, I.; Kluger, G.; Lerche, H.; Møller, R.S. Genetic and phenotypic heterogeneity suggest therapeutic implications in SCN2A-related disorders. Brain 2017,140,1316-1336.

[6] Chen, T.; Giri, M.; Xia, Z.; Subedi, Y.N.; Li, Y. Genetic and epigenetic mechanisms of epilepsy: a review. Neuropsychiatr Dis Treat 2017,13,1841-1859.

[7] McTague, A.; Howell, K.B.; Cross, J.H.; Kurian, M.A.; Scheffer, I.E. The genetic landscape of the epileptic encephalopathies of infancy and childhood. Lancet Neurol 2016,15, 304316.

[8] Scheffer, I.E.; Berkovic, S.; Capovilla, G.; Connolly, M.B.; French, J.; Guilhoto, L.; Hirsch, E.; Jain, S.; Mathern, G.W.; Moshé, S.L.; Nordli, D.R.; Perucca, E.; Tomson, T.; Wiebe, S.; Zhang, Y.H.; Zuberi, S.M. ILAE classification of the epilepsies: position paper of the ILAE Commission for Classification and Terminology. Epilepsia,2017,58(4),512-521.

[9] Blumcke, I.; Spreafico, R.; Haaker, G.; Coras, R.; Kobow, K.; Bien, C.G.; Pfäfflin, M.; Elger, C.; Widman, G.; Schramm, J.; Becker, A.; Braun, K.P.; Leijten, F.; Baayen, J.C.; Aronica, E.; Chassoux, F.; Hamer, H.; Stefan, H.; Rössler, K.; Thom, M.; Walker, M.C.; Sisodiya, S.M.; Duncan, J.S.; McEvoy, A.W.; Pieper, T.; Holthausen, H.; Kudernatsch, M.; Meencke, H.J.; Kahane, P.; Schulze-Bonhage, A.; Zentner, J.; Heiland, D.H.; Urbach, H.; Steinhoff, B.J.; Bast, T.; Tassi, L.; Lo Russo, G.; Özkara, C.; Oz, B.; Krsek, P.; Vogelgesang, S.; Runge, U.; Lerche, H.; Weber, Y.; Honavar, M.; Pimentel, J.; Arzimanoglou, A.; Ulate-Campos, A.; Noachtar, S.; Hartl, E.; Schijns, O.; Guerrini, R.; Barba, C.; Jacques, T.S.; Cross, J.H.; Feucht, M.; Mühlebner, A.; Grunwald, T.; Trinka, E.; Winkler, P.A.; Gil-Nagel, A.; Toledano Delgado, R.; Mayer, T.; Lutz, M.; Zountsas, B.; Garganis, K.; Rosenow, F.; Hermsen, A.; von Oertzen, T.J.; Diepgen, T.L.; Avanzini, G.; EEBB 
Consortium. Histopathological findings in brain tissue obtained during epilepsy surgery. $N$ Engl $J$ Med,2017,377(17):1648-1656.

[10] Heuser, K.; Nagelhus, E.A.; Tauboll, E.; Indahl, U.; Berg, P.R.; Lien, S.; Nakken, S.; Gjerstad, L.; Ottersen, O.P. Variants of the genes encoding AQP4 and Kir4.1 are associated with subgroups of patients with temporal lobe epilepsy. Epilepsy Research 2010,88,55-64.

[11] Gambardella, A.; Manna, I.; Labate, A.; Chifari, R.; La Russa, A.; Serra, P.; Cittadella, R.; Bonavita, S.; Andreoli, V.; Le Piane, E.; Sasanelli, F.; Di Costanzo, A.; Zappia, M.; Tedeschi, G.; Aguglia, U.; Quattrone, A. GABA(B) receptor 1 polymorphism $(\mathrm{G} 1465 \mathrm{~A})$ is associated with temporal lobe epilepsy. Neurology 2003,60,560-563.

[12] Pernhorst, K.; Raabe, A.; Niehusmann, P.; van Loo, K.M.; Grote, A.; Hoffmann ,P.; Cichon, S.; Sander, T.; Schoch, S.; Becker, A.J. Promoter variants determine gamma-aminobutyric acid homeostasis-related gene transcription in human epileptic hippocampi. Journal of Neuropathology and Experimental Neurology 2011,70,1080-1088.

[13] Lv, R.J.; He, J.S.; Fu, Y.H.; Zhang, Y.Q.; Shao, X.Q.; Wu, L.W.; Lu, Q.; Jin, L.R.; Liu, H. ASIC1a polymorphism is associated with temporal lobe epilepsy. Epilepsy Research 2011,96,74-80.

[14] Manna, I.; Labate, A.; Gambardella, A.; Forabosco, P.; La Russa A.; Le Piane E.; Aguglia, U; Quattrone, A. Serotonin transporter gene (5-Htt): association analysis with temporal lobe epilepsy. Neuroscience Letters 2007,421,52-56.

[15] Stefulj, J.; Bordukalo-Niksic, T.; Hecimovic, H.; Demarin, V.; Jernej, B. Epilepsy and serotonin (5HT): variations of 5HT-related genes in temporal lobe epilepsy. Neuroscience Letters 2010,478,29-31. 
[16] Li, J; Lin, H; Zhu, X; Li, L.; Wang, X.; Sun, W.; Wu, X.; Liu, A.; Niu, F.; Wang, Y.; Liu, Y. Association study of functional polymorphisms in serotonin transporter gene with temporal lobe epilepsy in Han Chinese population. Eur J Neurol 2012,19:351-353.

[17] Lv, R.J.; He, J.S.; Fu, Y.H., Shao, X.Q.; Wu, L.W.; Lu, Q.; Jin, L.R.; Liu, H. A polymorphism in CALHM1 is associated with temporal lobe epilepsy. Epilepsy Behav 2011,20,681-685.

[18] Stögmann, E.; Zimprich, A.; Baumgartner, C.; Aull-Watschinger, S.; Höllt, V.; Zimprich, F. A functional polymorphism in the prodynorphin gene promotor is associated with temporal lobe epilepsy. Ann Neurol 2002,51,260-263.

[19] Labate, A.; Manna, I.; Gambardella, A.; Le Piane, E.; La Russa, A.; Condino, F.; Cittadella, R.; Aguglia, U.; Quattrone A. Association between the M129V variant allele of PRNP gene and mild temporal lobe epilepsy in women. Neuroscience Letters 2007,421,1-4.

[20] Zhu, W.Y.; Jiang, P.; He, X.; Cao, L.J.; Zhang, L.H.; Dang, R.L.; Tang, M.M.; Xue, Y.; Li, H. Contribution of NRG1 gene polymorphisms in temporal lobe epilepsy. J Child Neurol 2016,31(3):271-276.

[21] Kasperaviciute, D.; Catarino, C.B.; Matarin, M.; Leu, C.; Novy, J.; Tostevin, A.; Leal, B.; Hessel, E.V.; Hallmann, K.; Hildebrand, M.S.; Dahl, H.H.; Ryten, M.; Trabzuni, D.; Ramasamy, A.; Alhusaini, S.; Doherty, C.P.; Dorn, T.; Hansen, J.; Krämer, G.; Steinhoff, B.J.; Zumsteg, D.; Duncan, S.; Kälviäinen, R.K.; Eriksson, K.J.; Kantanen, A.M.; Pandolfo, M.; GruberSedlmayr, U.; Schlachter, K.; Reinthaler, E.M.; Stogmann, E.; Zimprich, F.; Théâtre, E.; Smith, C.; O'Brien, T.J.; Meng Tan, K.; Petrovski, S.; Robbiano, A.; Paravidino, R.; Zara, F.; Striano, P.; Sperling, M.R.; Buono, R.J.; Hakonarson, H.; Chaves, J.; Costa, P.P.; Silva, B.M.; da Silva, A.M.; de Graan, P.N.; Koeleman, B.P.; Becker, A.; Schoch, S.; von Lehe, M.; Reif, P.S.; Rosenow, F.; Becker, F.; Weber, Y.; Lerche, H.; Rössler, K.; Buchfelder, M.; Hamer, H.M.; Kobow, K.; Coras, 
R.; Blumcke, I.; Scheffer, I.E.; Berkovic, S.F.; Weale, M.E.; UK Brain Expression Consortium; Delanty, N.; Depondt, C.; Cavalleri, G.L.; Kunz, W.S.; Sisodiya, S.M. Epilepsy, hippocampal sclerosis and febrile seizures linked by common genetic variation around SCN1A. Brain 2013,136:3140-3150.

[22] Jamali, S., Salzmann, A., Perroud, N., Ponsole-Lenfant, M.; Cillario, J.; Roll, P.; Roeckel-Trevisiol, N.; Crespel, A.; Balzar, J.; Schlachter, K.; Gruber-Sedlmayr, U.; Pataraia, E.; Baumgartner, C.; Zimprich, A.; Zimprich, F.; Malafosse, A.; Szepetowski, P. Functional variant in complement $\mathrm{C} 3$ gene promoter and genetic susceptibility to temporal lobe epilepsy and febrile seizures. PLoS One 2010,5(9). pii: e12740.

[23] Johnson, M.R.; Behmoaras, J.; Bottolo, L.; Krishnan, M.L.; Pernhorst, K.; Santoscoy, P.L.M.; Rossetti, T.; Speed, D.; Srivastava, P.K.; Chadeau-Hyam, M.; Hajji, N.; Dabrowska, A.; Rotival, M.; Razzaghi, B.; Kovac, S.; Wanisch, K.; Grillo, F.W.; Slaviero, A.; Langley, S.R.; Shkura, K.; Roncon, P.; De T.; Mattheisen, M.; Niehusmann, P.; O'Brien, T.J.; Petrovski, S.; von Lehe, M.; Hoffmann, P.; Eriksson, J.; Coffey, A.J.; Cichon, S.; Walker, M.; Simonato, M.; Danis, B.; Mazzuferi, M.; Foerch, P.; Schoch, S.; De Paola, V.; Kaminski, R.M.; Cunliffe, V.T.; Becker, A.J.; Petretto, E. Systems genetics identifies Sestrin 3 as a regulator of a proconvulsant gene network in human epileptic hippocampus. Nat Commun 2015,6,6031.

[24] Kanemoto, K.; Kawasaki, J.; Miyamoto, T.; Obayashi, H.; Nishimura, M. Interleukin (IL)1beta, IL-1alpha, and IL-1 receptor antagonist gene polymorphisms in patients with temporal lobe epilepsy. Ann Neurol 2000,47,571-574.

[25] Salzmann, A.; Perroud, N.; Crespel, A.; Lambercy, C.; Malafosse, A. Candidate genes for temporal lobe epilepsy: a replication study. Neurol Sci 2008,29: 397-403. 
[26] Haerian, B.S.; Shaari, H.M.; Fong, C.Y.; et al. Contribution of TIMP4 rs3755724 polymorphism to susceptibility to focal epilepsy in Malaysian Chinese. Journal of Neuroimmunology 2015,278,137-143.

[27] Liu, Z.; Yin, X.; Liu, L.; et al. Association of KEAP1 and NFE2L2 polymorphisms with temporal lobe epilepsy and drug resistant epilepsy. Gene 2015,571,231-236.

[28] Fedele, D.E.; Li, T.; Lan, J.Q.; Fredholm, B.B.; Boison, D. Adenosine A1 receptors are crucial in keeping an epileptic focus localized. Exp Neurol 2006,200(1):184-190.

[29] Kochanek, P.M.; Vagni, V.A.; Janesko, K.L.; et al. Adenosine A1 receptor knockout mice develop lethal status epilepticus after experimental traumatic brain injury. J Cereb Blood Flow Metab 2006,26,565-575.

[30] Wagner, A.K.; Miller, M.A.; Scanlon, J.; Ren, D.; Kochanek, P.M.; Conley, Y.P. Adenosine A1 receptor gene variants associated with post-traumatic seizures after severe TBI. Epilepsy research 2010,90(3):259-272.

[31] Diaz-Arrastia, R.; Gong, Y.; Fair, S.; Scott, K.D.; Garcia, M.C.; Carlile, M.C.; Agostini, M.A.; Van Ness, P.C. Increased risk of late posttraumatic seizures associated with inheritance of APOE epsilon4 allele. Arch Neurol 2003,60,818-822.

[32] Darrah, S.D.; Miller, M.A.; Ren, D.; Hoh, N.Z.; Scanlon, J.M.; Conley, Y.P.; Wagner, A.K. Genetic variability in glutamic acid decarboxylase genes: associations with post-traumatic seizures after severe TBI. Epilepsy Research 2013,103,180-194.

[33] Ritter, A.C.; Kammerer, C.M.; Brooks, M.M.; Conley, Y.P.; Wagner, A.K. Genetic variation in neuronal glutamate transport genes and associations with post-traumatic seizure. Epilepsia 2016,57(6),984-993. 
[34] Diamond, M.L.; Ritter, A.C.; Failla, M.D.; Boles, J.A.; Conley, Y.P.; Kochanek, P.M.; Wagner, A.K. IL-1beta associations with posttraumatic epilepsy development: a genetics and biomarker cohort study. Epilepsia 2014,55,1109-1119.

[35] Scher, A.I.; Wu, H.; Tsao, J.W.; Blom, H.J.; Feit, P.; Nevin, R.L.; Schwab, K.A. MTHFR C677T genotype as a risk factor for epilepsy including post-traumatic epilepsy in a representative military cohort. Journal of Neurotrauma 2011,28,1739-1745.

[36] Zhang, B.; Chen, M.; Yang, H.; Wu, T.; Song, C.; Guo, R. Evidence for involvement of the CD40/CD40L system in post-stroke epilepsy. Neurosci Lett 2014,567, 6-10.

[37] Yang, H.; Song, Z.; Yang, GP.; et al. The ALDH2 rs671 polymorphism affects poststroke epilepsy susceptibility and plasma 4-HNE levels. PLoS One 2014,9: e109634

[38] Vezzani, A.; Maroso, M.; Balosso, S.; Sanchez, M.A.; Bartfai, T. IL-1 receptor/Tolllike receptor signaling in infection, inflammation, stress and neurodegeneration couples hyperexcitability and seizures. Brain Behav Immun 2011,25,1281-1289.

[39] Vezzani, A.; Viviani, B. Neuromodulatory properties of inflammatory cytokines and their impact on neuronal excitability. Neuropharmacology 2015,96,70-82.

[40] Liimatainen, S.; Fallah, M.; Kharazmi, E.; Peltola, M.; Peltola, J. Interleukin-6 levels are increased in temporal lobe epilepsy but not in extra-temporal lobe epilepsy. J Neurol 2009,256, 796-802.

[41] de Vries, E.E.; van den Munckhof, B.; Braun, K.P.; van Royen-Kerkhof, A.; de Jager, W.; Jansen, F.E. Inflammatory mediators in human epilepsy: a systematic review and metaanalysis. Neurosci Biobehav Rev 2016,63,177-190.

[42] Alapirtti, T.; Lehtimäki, K.; Nieminen, R.; Mäkinen, R.; Raitanen, J.; Moilanen, E.; Mäkinen, J.; Peltola, J. The production of IL-6 in acute epileptic seizure: a video-EEG study. $J$ 
Neuroimmunol 2017. pii: S0165-5728(17)30079-6. doi: 10.1016/j.jneuroim.2017.12.008. [Epub ahead of print]

[43] Lehtimäki, K.A.; Keränen, T.; Huhtala, H.; Hurme, M.; Ollikainen, J.; Honkaniemi, J.; Palmio, J.; Peltola, J. Regulation of IL-6 system in cerebrospinal fluid and serum compartments by seizures: the effect of seizure type and duration. J Neuroimmunol 2004,152,121-125.

[44] Pollard, J.R.; Eidelman, O.; Mueller, G.P.; Dalgard, C.L.; Crino, P.B.; Anderson, C.T.; Brand, E.J.; Burakgazi, E.; Ivaturi, S.K.; Pollard, H.B. The TARC/sICAM5 ratio in patient plasma is a candidate biomarker for drug resistant epilepsy. Front Neurol 2012,3,181.

[45] Gallentine, W.B.; Shinnar, S.; Hesdorffer, D.C.; Epstein, L.; Nordli, D.R. Jr; Lewis, D.V.; Frank, L.M.; Seinfeld, S.; Shinnar, R.C.; Cornett, K.; Liu, B.; Moshé, S.L.; Sun, S.; FEBSTAT investigator team. Plasma cytokines associated with febrile status epilepticus in children: a potential biomarker for acute hippocampal injury. Epilepsia 2017,58(6),1102-1111.

[46] Sundararajan, T.; Tesar, G.E.; Jimenez, X.F. Biomarkers in the diagnosis and study of psychogenic nonepileptic seizures: a systematic review. Seizure 2016,35,11-22.

[47] Chen, D.K.; So, Y.T.; Fisher, R.S. Use of serum prolactin in diagnosing epileptic seizures report of the therapeutics and technology assessment Subcommittee of the American Academy of Neurology. Neurology 2005,65(5),668-675.

[48] Fisher, R.S.; Chan, D.W.; Bare, M.; Lesser, R.P. Capillary prolactin measurement for diagnosis of seizures. Ann Neurol 1991,29(2),187-90.

[49] Lusić, I.; Pintarić, I.; Hozo, I.; Boić, L.; Capkun, V. Serum prolactin levels after seizure and syncopal attacks. Seizure 1999,8(4),218-222.

[50] Ahmad, S.; Beckett, M.W. Value of serum prolactin in the management of syncope. Emerg Med J 2004,21(2):e3 
[51] Alving, J. Serum prolactin levels are elevated also after pseudoepileptic seizures. Seizure 1998,7(2),85-89.

[52] Shukla, G.; Bhatia, M.; Vivekanandhan, S.; Gupta, N.; Tripathi, M.; Srivastava, A.; et al. Serum prolactin levels for differentiation of nonepileptic versus true seizures: limited utility. Epilepsy Behav 2004,5(4),517-521.

[53] Gallagher, B.B. Endocrine abnormalities in human temporal lobe epilepsy. Yale J Biol Med 1987,60(2):93.

[54] Gallagher, B.B.; Murvin, A.; Flanigin, H.F.; King, D.W.; Luney, D. Pituitary and adrenal function in epileptic patients. Epilepsia 1984,25(6),683-689.

[55] Pritchard, P.B.; Wannamaker, B.B.; Sagel, J.; Daniel C.M. Serum prolactin and cortisol levels in evaluation of pseudoepileptic seizures. Ann Neurol 1985,18(1),87-89.

[56] Rao, M.L.; Stefan, H.; Bauer, J. Epileptic but not psychogenic seizures are accompanied by simultaneous elevation of serum pituitary hormones and cortisol levels. Neuroendocrinology 1989,49(1):33-39.

[57] Mehta, S.R.; Dham, S.K.; Lazar, A.I.; Narayanswamy, A.S.; Prasad, G.S. Prolactin and cortisol levels in seizure disorders. J Assoc Phys India 1994,42(9),709-712.

[58] Tunca, Z.; Ergene, U“; Fidaner, H.; Cimilli, C.; O“zerdem, A.; Alkin, T., et al. Reevaluation of serum cortisol in conversion disorder with seizure (pseudoseizure). Psychosomatics 2000,41(2), $152-153$.

[59] Silvestri, N.J.; Wolfe, G.I. Asymptomatic/pauci-symptomatic creatine kinase elevations (hyperckemia). Muscle Nerve 2013,47(6):805-815. 
[60] Kyriakides, T.; Angelini, C.; Schaefer, J.; Sacconi, S.; Siciliano, G.; Vilchez, J.J.; et al. EFNS guidelines on the diagnostic approach to pauci-or asymptomatic hyperCK-emia. Eur $J$ Neurol 2010,17(6),767-773.

[61] Willert, C.; Spitzer, C.; Kusserow, S.; Runge, U. Serum neuron-specific enolase, prolactin, and creatine kinase after epileptic and psychogenic non-epileptic seizures. Acta Neurol Scand 2004,109(5),318-323.

[62] Holtkamp, M.; Othman, J.; Buchheim, K.; Meierkord, H. Diagnosis of psychogenic nonepileptic status epilepticus in the emergency setting. Neurology 2006,66(11),1727-1729.

[63] Petramfar, P.; Yaghoobi, E.; Nemati, R.; Asadi-Pooya, A.A. Serum creatine phosphokinase is helpful in distinguishing generalized tonic-clonic seizures from psychogenic nonepileptic seizures and vasovagal syncope. Epilepsy Behav 2009,15(3),330-332.

[64] Wyllie, E.; Lueders, H.; Pippenger, C.; VanLente, F. Postictal serum creatine kinase in the diagnosis of seizure disorders. Arch Neurol 1985,42(2):123-6.

[65] DeGiorgio, C.M.; Heck, C.N.; Rabinowicz, A.L.; Gott, P.S.; Smith, T.; Correale, J. Serum neuron-specific enolase in the major subtypes of status epilepticus. Neurology 1999,52(4),746.

[66] Tanabe, T.; Suzuki, S.; Hara, K.; Shimakawa, S.; Wakamiya, E.; Tamai, H. Cerebrospinal fluid and serum neuron-specific enolase levels after febrile seizures. Epilepsia 2001,42(4),504-507.

[67] Tumani, H.; Otto, M.; Gefeller, O.; Wiltfang, J.; Herrendorf, G.; Mogge, S.; et al. Kinetics of serum neuron-specific enolase and prolactin in patients after single epileptic seizures. Epilepsia 1999,40(6),713-718.

[68] Lee, S.Y.; Choi, Y.C.; Kim, J.H.; Kim, W.J. Serum neuron-specific enolase level as a biomarker in differential diagnosis of seizure and syncope. J Neurol 2010,257(10),1708-1712. 
[69] Rabinowicz, A.L.; Correale, J.; Boutros, R.B.; Couldwell, W.T.; Henderson, C.W.; DeGiorgio, C.M. Neuron-specific enolase is increased after single seizures during inpatient video/EEG monitoring. Epilepsia 1996,37(2),122-125.

[70] Johnsson, P.; Blomquist, S.; Lu“ hrs, C.; Malmkvist, G.; Alling, C.; Solem, J.O.; et al. Neuron-specific enolase increases in plasma during and immediately after extracorporeal circulation. Ann Thorac Surg 2000;69(3),750-754.

[71] Ramont, L.; Thoannes, H.; Volondat, A.; Chastang, F.; Millet, M.C.; Maquart, F.X. Effects of hemolysis and storage condition on neuron-specific enolase (NSE) in cerebrospinal fluid and serum: implications in clinical practice. Clin Chem Lab Med 2005,43(11),1215-1217.

[72] Henshall, D.C.; Kobow, K. Epigenetics and Epilepsy. Cold Spring Harbor perspectives in medicine 2015. 5.

[73] Cattani, A.A.; Allene, C.; Seifert, V.; Rosenow, F.; Henshall, D.C.; Freiman, T.M. Involvement of microRNAs in epileptogenesis. Epilepsia 2016,57,1015-1026.

[74] Jin, X.F.; Wu, N.; Wang, L.; Li, J. Circulating microRNAs: a novel class of potential biomarkers for diagnosing and prognosing central nervous system diseases. Cellular and molecular neurobiology 2013,33,601-613.

75 LEE E AMBROS 2001

[76] Etheridge, A.; Lee, I.; Hood, L.; Galas, D.; Wang, K. Extracellular microRNA: a new source of biomarkers. Mutat Res 2011,717,85-90.

[77] Henshall, D.C.; Hamer, H.M.; Pasterkamp, R.J.; Goldstein, D.B.; Kjems, J.; Prehn, J.H.M.; Schorge, S.; Lamottke, K.; Rosenow, F. MicroRNAs in epilepsy: pathophysiology and clinical utility. Lancet neurology 2016,15,1368-1376. 
[78] Brennan, G.P.; Henshall, D.C. MicroRNAs in the pathophysiology of epilepsy. Neuroscience letters 2017.

[79] Kan, A.A.; van Erp, S., Derijck; A.A.; de Wit, M.; Hessel, E.V.; O'Duibhir, E.; de Jager, W.; Van Rijen, P.C.; Gosselaar, P.H.; de Graan, P.N.; Pasterkamp, R.J. Genome-wide microRNA profiling of human temporal lobe epilepsy identifies modulators of the immune response. Cellular and molecular life sciences CMLS 2012,69,3127-3145.

[80] Wang, J.; Yu, J.T.; Tan, L.; Tian, Y.; Ma, J.; Tan, C.C.; Wang, H.F.; Liu, Y.; Tan, M.S.; Jiang, T.; Tan, L. Genome-wide circulating microRNA expression profiling indicates biomarkers for epilepsy. Scientific reports $\mathbf{2 0 1 5 , 5 , 9 5 2 2 .}$

[81] Sun, Y.; Wang, X.; Wang, Z.; Zhang, Y.; Che, N.; Luo, X.; Tan, Z.; Sun, X.; Li, X.; Yang, K.; Wang, G.; Luan, L.; Liu, Y.; Zheng, X.; Wei, M.; Cheng, H.; Yin, J. Expression of microRNA-129-2-3p and microRNA-935 in plasma and brain tissue of human refractory epilepsy. Epilepsy Research 2016,127,276-283.

[82] An, N.; Zhao, W.; Liu, Y.; Yang, X.; Chen, P. Elevated serum miR-106b and miR-146a in patients with focal and generalized epilepsy. Epilepsy research 2016,127,311-316.

[83] Wang, X.; Sun, Y.; Tan, Z.; Che, N.; Ji, A.; Luo, X.; Sun, X.; Li, X.; Yang, K.; Wang, G.; Luan, L.; Liu, Y.; Wei, M.; Yin, J. Serum MicroRNA-4521 is a potential biomarker for focal cortical dysplasia with refractory epilepsy. Neurochem Res 2016,41(4),905-912.

[84] Aydin, S.; Dag, E.; Ozkan, Y.; Arslan, O.; Koc, G.; Bek, S.; et al. Time dependent changes in the serum levels of prolactin, nesfatin-1 and ghrelin as a marker of epileptic attacks in young male patients. Peptides 2011,32(6):1276-1280.

[85] Jackson, G.D.; Connelly, A.; Duncan, J.S.; et al. Optimizing the diagnosis of hippocampal sclerosis using MR imaging. AJNR Am J Neuroradiol 1993,14,758-762. 
[86] Briellmann, R.S.; Pell, G.S.; Wellard, R.M.; Mitchell, L.A.; Abbott, D.F.; Jackson, G.D. MR imaging of epilepsy: state of the art at $1.5 \mathrm{~T}$ and potential of $3 \mathrm{~T}$. Epileptic Disord 2003,5,3-20.

[87] Labate, A.; Gambardella, A.; Aguglia U.; et al. Temporal lobe abnormalities on brain MRI in healthy volunteers: a prospective case-control study. Neurology 2010,74,553-557.

[88] Zarow, C.; Sitzer, T.E.; Chui, H.C. Understanding HS in the elderly: epidemiology, characterization, and diagnostic issues. Curr Neurol Neurosci Rep 2008,8,363-370.

[89] Labate, A.; Gambardella, A.; Andermann, E.; Aguglia, U.; Cendes, F.; Berkovic, S.F.; Andermann F. Benign mesial temporal lobe epilepsy. Nat Rev Neurol. 2011b;7:237-40.

[90] Labate, A.; Aguglia, U.; Tripepi, G.; et al. Long-term outcome of mild mesial temporal lobe epilepsy: a prospective longitudinal cohort study. Neurology 2016,86,1904-1910.

[91] Aguglia, U.; Beghi, E.; Labate, A.; Condino, F.; Cianci, V.; Mumoli, L.; Gasparini, S.; Quattrone, A.; Gambardella, A. Age at onset predicts good seizure outcome in sporadic nonlesional and mesial temporal sclerosis based temporal lobe epilepsy. J Neurol Neurosurg Psychiatry 2011,82,555-559.

[92] Labate, A.; Cerasa, A.; Gambardella, A.; Aguglia, U.; Quattrone A. Hippocampal and thalamic atrophy in mild temporal lobe epilepsy: a VBM study. Neurology 2008,71,1094-1101.

[93] Labate, A.; Cerasa, A.; Aguglia, U.; Mumoli, L.; Quattrone, A.; Gambardella, A. Neocortical thinning in "benign" mesial temporal lobe epilepsy. Epilepsia 2011,52,712-717.

[94] Mumoli, L.; Labate, A.; Vasta, R.; Cherubini, A.; Ferlazzo, E.; Aguglia, U.; Quattrone, A.; Gambardella, A. Detection of hippocampal atrophy in patients with temporal lobe epilepsy: a 3Tesla MRI shape. Epilepsy Behav 2013,28,489-493. 
[95] Labate, A.; Cherubini, A.; Tripepi, G.; et al. White matter abnormalities differentiate severe from benign temporal lobe epilepsy. Epilepsia 2015,56,1109-1116.

[96] Caligiuri, M.E.; Labate, A.; Cherubini, A.; et al. Integrity of the corpus callosum in patients with benign temporal lobe epilepsy. Epilepsia 2016,57,590-596.

[97] Colombo, N.; Tassi, L.; Galli, C.; et al. Focal cortical dysplasias: MR imaging, histopathologic, and clinical correlations in surgically treated patients with epilepsy. Am J Neuroradiol 2003,24,724-733.

[98] Faulkner, H.J.; Sandeman, D.R.; Love, S.; Likeman, M.J.; Nunez DA, Lhatoo, S.D. Epilepsy surgery for refractory epilepsy due to encephalocele: a case report and review of the literature. Epileptic Disord 2010,12,160-166.

[99] Barkovich, A.J.; Guerrini, R.; Kuzniecky, R.I.; Jackson, G.D.; Dobyns, W.B. A developmental and genetic classification for malformations of cortical development: update 2012. Brain 2012,135,1348-1369.

[100] Gasparini, S.; Ferlazzo, E.; Pustorino, G.; Ascoli, M.; Cianci, V.; Sueri, C.; Calabrò, S.; Campello, M.; Africa, E.; Gangemi, A.; Versace, P.; Aguglia, U. The epileptogenic role of occult temporal encephalo-meningocele: a case control study. Neurology 2018, accepted. Doi....

[101] Blümcke, I.; Thom, M.; Aronica, E.; Armstrong, D.D.; Vinters, H.V.; Palmini, A.; Jacques, T.S.; Avanzini, G.; Barkovich, A.J.; Battaglia, G.; Becker, A.; Cepeda, C.; Cendes, F.; Colombo, N.; Crino, P.; Cross, J.H.; Delalande, O.; Dubeau, F.; Duncan, J.; Guerrini, R.; Kahane, P.; Mathern, G.; Najm, I.; Ozkara, C.; Raybaud, C.; Represa, A.; Roper, S.N; Salamon, N.; SchulzeBonhage, A.; Tassi, L.; Vezzani, A.; Spreafico, R. The clinicopathologic spectrum of focal cortical dysplasias: a consensus classification proposed by an ad hoc Task Force of the ILAE Diagnostic Methods Commission. Epilepsia 2011,52,158-174. 
[102] Saavalainen, T.; Jutila, L.; Mervaala, E.; Kälviäinen, R.; Vanninen, R.; Immonen, A. Temporal antero inferior encephalocele: an under recognized etiology of temporal lobe epilepsy? Neurology 2015,85,1467-1474.

[103] Boumaa, H.K.; Labos, C.; Gore, G.C.; Wolfson, C.; Keezer, M.R. The diagnostic accuracy of routine electroencephalography after a first unprovoked seizure. European Journal of Neurology 2016,23,455-463.

[104] Aguglia, U.; Gambardella, A.; Quartarone, A.; Girlanda, P.; Le Piane, E.; Messina, D.; Oliveri, R.L.; Zappia, M.; Quattrone, A. Interhemispheric threshold differences in idiopathic generalized epilepsies with versive or circling seizures determined with focal magnetic transcranial stimulation. Epilepsy Res 2000,40(1),1-6.

[105] Wright, M.A.; Orth, M.; Patsalos, P.N.; Smith, S.J.; Richardson, M.P. Cortical excitability predicts seizures in acutely drug-reduced temporal lobe epilepsy patients. Neurology 2006,67(9),1646-1651.

[106] Badawy, R.; Macdonell, R.; Jackson, G.; Berkovic, S. The peri-ictal state: cortical excitability changes within 24 h of a seizure. Brain 2009,132(Pt 4),1013-1021.

[107] Virtanen et al., Instrumentation for the measurement of electric brain responses to transcranial magnetic stimulation. Med Biol Eng Comput 1999,37,322-326.

[108] Ilmoniemi and Kičić. Methodology for combined TMS and EEG. Brain Topogr 2010,22,233-248.

[109] Rosanova et al., Natural frequencies of human corticothalamic circuits. J Neurosci 2009,29,7679-7685.

[110] Casali et al., General indices to characterize the electrical response of the cerebral cortex to TMS. Neuroimage 2010,49,1459-1468. 
[111] Rosanova, M.; Casarotto, S.; Pigorini, A.; Canali, P.; Casali, A.G.; Massimini, M. Combining transcranial magnetic stimulation with electroencephalography to study human cortical excitability and effective connectivity. In: Neuromethods series, Neuronal Network Analysis: Concepts and Experimental Approaches. T Fellin, M Halassa Eds., Humana Press, Springer Science + Business Media. Vol. 67, pp. 435-457. DOI: 10.1007/7657_2011_15

[112] Farzan, F.; Vernet, M.; Shafi, M.M.; Rotenberg, A.; Daskalakis, Z.J.; Pascual-Leone, A. Characterizing and modulating brain circuitry through transcranial magnetic stimulation combined with electroencephalography. Frontiers in Neural Circuits 2016,10,73.

[113] Valentin, A.; Arunachalam, R.; Mesquita-Rodrigues, A.; Garcia Seoane, J.J.; Richardson, M.P.; Mills, K.R.; Alarcon, G. Late EEG responses triggered by transcranial magnetic stimulation (TMS) in the evaluation of focal epilepsy. Epilepsia 2008,49,470-480.

[114] Shafi, M.M.; Vernet, M.; Klooster, D.; Chu, C.J.; Boric, K.; Barnard, M.E.; Romatoski, K.; Westover, M.B.; Christodoulou, J.A.; Gabrieli, J.D.; Whitfield-Gabrieli, S.; Pascual-Leone, A.; Chang, B.S. Physiological consequences of abnormal connectivity in a developmental epilepsy. Ann Neurol 2015,77,487-503.

[115] Del Felice, A.; Fiaschi, A.; Bongiovanni, G.L.; Savazzi, S.; Manganotti, P. The sleepdeprived brain in normals and patients with juvenile myoclonic epilepsy: a perturbational approach to measuring cortical reactivity. Epilepsy Research 2011,96,123-131.

[116] Kimiskidis, V.K.; Tsimpiris, A.; Ryvlin, P.; Kalviainen, R.; Koutroumanidis, M.; Valentin, A.; Laskaris, N.; Kugiumtzis, D. TMS combined with EEG in genetic generalized epilepsy: a phase II diagnostic accuracy study. Clin Neurophysiol 2017,128,367-381.

[117] Atluri, S.; Frehlich, M.; Mei, Y.; Garcia Dominguez, L.; Rogasch, N.C.; Wong, W.; Daskalakis, Z.J.; Farzan, F. TMS-EEG: a MATLAB-based graphical user interface for processing 
electrophysiological signals during transcranial magnetic stimulation. Frontiers in neural circuits 2016,10,78.

[118] Zijlmans, M.; Worrell, G.A.; Dümpelmann, M.; Stieglitz, T.; Barborica, A.; Heers, M.; Ikeda, A.; Usui, N.; Le Van Quyen, M. How to record high-frequency oscillations in epilepsy: a practical guideline. Epilepsia 2017,58,1305-1315.

[119] Jacobs, J.; LeVan, P.; Chander, R.; et al. Interictal high-frequency oscillations (80-500 $\mathrm{Hz}$ ) are an indicator of seizure onset areas independent of spikes in the human epileptic brain. Epilepsia 2008,49,1893-1907.

[120] Wang, S.; Wang, I.Z.; Bulacio, J.C.; et al. Ripple classification helps to localize the seizure-onset zone in neocortical epilepsy. Epilepsia 2013,54,370-376.

[121] Burnos, S.; Frauscher, B.; Zelmann, R.; et al. The morphology of high frequency oscillations (HFO) does not improve delineating the epileptogenic zone. Clin Neurophysiol 2016,127,2140-2148.

[122] Jirsch, J.D.; Urrestarazu, E.; LeVan, P.; et al. High-frequency oscillations during human focal seizures. Brain 2006,129,1593-1608.

[123] Khosravani, H.; Mehrotra, N.; Rigby, M.; et al. Spatial localization and timedependant changes of electrographic high frequency oscillations in human temporal lobe epilepsy. Epilepsia 2009,50,605-616.

[124] Zijlmans, M.; Jacobs, J.; Kahn, Y.U.; et al. Ictal and interictal high frequency oscillations in patients with focal epilepsy. Clin Neurophysiol 2011,122,664-671.

[125] Jacobs, J.; Staba, R.; Asano, E.; et al. High-frequency oscillations (HFOs) in clinical epilepsy. Prog Neurobiol 2012,98,302-315. 
[126] van 't Klooster, M.A.; Zijlmans, M., Leijten, F.S.; et al. Time-frequency analysis of single pulse electrical stimulation to assist delineation of epileptogenic cortex. Brain 2011,134,2855-2866.

[127] Haegelen, C.; Perucca, P.; Châtillon, C.E.; et al. High-frequency oscillations, extent of surgical resection, and surgical outcome in drug-resistant focal epilepsy. Epilepsia 2013,54,848857.

[128] van Klink, N.E.; van 't Klooster, M.A.; Zelmann, R.; et al. High frequency oscillations in intra-operative electrocorticography before and after epilepsy surgery. Clin Neurophysiol $\mathbf{2 0 1 4}, 125,2212-2219$.

[129] Usui, N.; Terada, K.; Baba, K.; et al. Significance of very-high-frequency oscillations (over 1,000 Hz) in epilepsy. Ann Neurol 2015,78,295-302.

[130] Zijlmans, M.; Jacobs, J.; Zelmann, R.; et al. High frequency oscillations and seizure frequency in patients with focal epilepsy. Epilepsy Res 2009,85,287-292.

[131] Jacobs, J.; Levan, P.; Ch^atillon, C.E.; et al. High frequency oscillations in intracranial EEGs mark epileptogenicity rather than lesion type. Brain 2009,132,1022-1037.

[132] Kerber, K.; LeVan, P.; D€umpelmann M,; et al. High frequency oscillations mirror disease activity in patients with focal cortical dysplasia. Epilepsia 2013,54,1428-1436.

[133] Ferrari-Marinho, T.; Perruca, P.; Mok, K.; et al. Pathological substrates of focal epilepsy influence the generation of high-frequency oscillations. Epilepsia 2015,56,592-598.

[134] Kobayashi, K.; Oka, M.; Akiyama, T.; et al. Very fast rhythmic activity on scalp EEG associated with epileptic spasms. Epilepsia 2004,45,488-496. 
[135] Inoue, T.; Kobayashi, K.; Oka, M.; et al. Spectral characteristics of EEG gamma rhythms associated with epileptic spasms. BrainDev 2008,30,321-328.

[136] Kobayashi, K.; Inoue, T.; Watanabe, Y.; et al. Spectral analysis of EEG gamma rhythms associated with tonic seizures in Lennox-Gastaut syndrome. Epilepsy Res 2009,86,15-22.

[137] Andrade-Valenca, L.P.; Dubeau, F.; Mari, F.; et al. Interictal scalp fast oscillations as a marker of the seizure onset zone. Neurology 2011,77,524-531.

[138] Pizzo, F.; Ferrari-Marinho, T.; Amiri, M.; et al. When spikes are symmetric, ripples are not: bilateral spike and wave above $80 \mathrm{~Hz}$ in focal and generalized epilepsy. Clin Neurophysiol 2016,127,1794-1802.

[139] Hu, K.; Xie, Y.Y.; Zhang, C.; Ouyang, D.S.; Long, H.Y.; Sun, D.N.; Long, L.L.; Feng, L.; Li, Y.; Xiao, B. MicroRNA expression profile of the hippocampus in a rat model of temporal lobe epilepsy and miR-34a-targeted neuroprotection against hippocampal neurone cell apoptosis post-status epilepticus. BMC Neurosci 2012,13,115.

[140] Bot, A.M.; Debski, K.J.; Lukasiuk, K. Alterations in miRNA levels in the dentate gyrus in epileptic rats. PLoS One 2013,8,e76051.

[141] Wang, J.; Tan, L.; Tan, L.; Tian, Y.; Ma, J.; Tan, C.C.; Wang, H.F.; Liu, Y.; Tan, M.S.; Jiang, T.; Yu, J.T. Circulating microRNAs are promising novel biomarkers for drug-resistant epilepsy. Sci Rep 2015,5,10201.

[142] Aronica, E.; Fluiter, K.; Iyer, A.; Zurolo, E.; Vreijling, J.; van Vliet, E.A.; Baayen, J.C.; Gorter, J.A. Expression pattern of miR-146a, an inflammation-associated microRNA, in experimental and human temporal lobe epilepsy. Eur J Neurosci 2010,31,1100-1107. 
[143] He, F.; Liu, B.; Meng, Q.; Sun, Y.; Wang, W.; Wang, C. Modulation of miR146a/complement factor H-mediated inflammatory responses in a rat model of temporal lobe epilepsy. Biosci Rep 2016,36. 
Table 1. Recent studies assessing miRNAs as diagnostic biomarkers in epilepsy.

\begin{tabular}{|c|c|c|c|c|}
\hline miRNAs & Expression & Clinical studies & $\begin{array}{l}\text { Human } \\
\text { samples }\end{array}$ & Preclinical studies \\
\hline $\begin{array}{c}\operatorname{miR}-106 b-5 p \\
{[80]}\end{array}$ & $\begin{array}{l}\mathrm{Up}- \\
\text { regulated }\end{array}$ & $\begin{array}{c}\text { Multiphase case- } \\
\text { control study on } 147 \\
\text { PWE and } 142 \\
\text { controls }\end{array}$ & Serum & None \\
\hline $\begin{array}{c}\operatorname{miR}-301 a-3 p \\
{[139-141]}\end{array}$ & $\begin{array}{l}\text { Down- } \\
\text { regulated }\end{array}$ & $\begin{array}{l}\text { Multiphase case- } \\
\text { control study on } 107 \\
\text { patients with } \\
\text { refractory epilepsy, } \\
111 \text { with responsive } \\
\text { epilepsy and } 85 \\
\text { controls }\end{array}$ & Serum & $\begin{array}{l}\text { TLE rat model } \\
\text { (lithium- } \\
\text { pilocarpine model) } \\
\text { and status } \\
\text { epilepticus rat } \\
\text { model evoked by } \\
\text { amygdala } \\
\text { stimulation }\end{array}$ \\
\hline $\begin{array}{c}\text { miR-129-2-3p } \\
\quad[81,140]\end{array}$ & $\begin{array}{l}\text { Up- } \\
\text { regulated }\end{array}$ & $\begin{array}{l}\text { Multiphase case- } \\
\text { control study on } 25 \\
\text { patients with } \\
\text { refractory TLE and } \\
25 \text { controls }\end{array}$ & $\begin{array}{l}\text { Cortical } \\
\text { brain } \\
\text { tissue } \\
\text { and } \\
\text { plasma }\end{array}$ & $\begin{array}{l}\text { Sstatus epilepticus } \\
\text { rat model evoked } \\
\text { by amygdala } \\
\text { stimulation }\end{array}$ \\
\hline $\begin{array}{l}\operatorname{miR}-4521 \\
{[83]}\end{array}$ & $\begin{array}{l}\text { Up- } \\
\text { regulated }\end{array}$ & $\begin{array}{c}\text { Randomized } \\
\text { controlled study on } \\
9 \text { patients with } \\
\text { refractory TLE } \\
\text { (with HS) } 8 \text { controls }\end{array}$ & $\begin{array}{l}\text { Cortical } \\
\text { brain } \\
\text { tissue } \\
\text { and } \\
\text { serum } \\
\end{array}$ & None \\
\hline $\begin{array}{c}\text { miR-146a and } \\
\text { miR-106b } \\
{[82,142]}\end{array}$ & $\begin{array}{l}\text { Up- } \\
\text { regulated }\end{array}$ & $\begin{array}{l}\text { Case-control study } \\
\text { on } 90 \text { subjects with } \\
\text { symptomatic, } \\
\text { idiopathic or } \\
\text { cryptogenic } \\
\text { epilepsy and } 90 \\
\text { controls }\end{array}$ & Serum & $\begin{array}{l}\text { TLE rat model } \\
\text { evoked by } \\
\text { hippocampal } \\
\text { electrical } \\
\text { stimulation }\end{array}$ \\
\hline $\begin{array}{l}\operatorname{miR}-146^{\circ} \\
{[142,143]}\end{array}$ & $\begin{array}{l}\text { Up- } \\
\text { regulated }\end{array}$ & $\begin{array}{l}\text { Case control study } \\
\text { on } 10 \text { patient with } \\
\text { refractory TLE (6 } \\
\text { with HS) and } 5 \\
\text { controls } \\
\end{array}$ & $\begin{array}{l}\text { Cortical } \\
\text { brain } \\
\text { tissue }\end{array}$ & $\begin{array}{l}\text { TLE rat model } \\
\text { evoked by } \\
\text { hippocampal } \\
\text { electrical } \\
\text { stimulation } \\
\end{array}$ \\
\hline
\end{tabular}

